same time they will be participating in the final stages of a substantial experiment. Throughout the year we will be monitoring their progress, and that of students at some conventional universities and colleges who are also using the Course or parts of it. For only this will tell us how close we are to our ultimate objective $-a$ first rate and comprehensive second level genetics teaching Course which can be widely used in Britain and abroad.

\section{Environmental protection under state socialism}

In the Soviet Union environmental issues have surfaced in recent years as just one consequence of the country's rapid development. The problems seem as intractable there as anywhere else. Vera Rich reports.

ECOLOGICAL problems seem to be as much a concern of the Soviet Union as they are of other industrialised countries. The prospectus for the Five-Year Plan lays considerable stress upon conservation and environmental protection, and the science and technology section includes among its major aims: "to study the scientific principles of the use and conservation of soils, mineral resources, the plant and animal worlds, the air, and water basins. To expand complex investigations of the world's oceans. To effect the further development of methods of forecasting the weather and natural disasters".

Commenting on this programme in the English-language Moscow News (No. 1, 1976), Academician Inokentii Gerasimov implies that the problem of conservation, although a real one, arising from rapid urbanisation and industrialisation, is nevertheless qualitatively different from that in capitalist countries: in the Soviet Union, he argues, "there are no social reasons for for the irrational utilisation of natural wealth. Environmental protection under socialism, with its planned economy and no privately owned natural resources, becomes an important task of the state. Hence, environmental protection in our country is part of the current and long-term economic plans".

Taken at its face value, Gerasimov's comment would imply that, in the Soviet Union, any ecological hazard would be of a short-term nature only: the result of a temporary imbalance between one part of the Plan and another. Such short-term imbalances do occur, and at a fairly low level of the administrative hierarchy may become the subject of criticism in the media. Last November, for example. Minsk Radio noted that reafforestation (to replace planned felling) in Byelorussia was falling behind schedule, while in the Brest, Minsk and Grodno Oblasts, excessive felling had taken place and the authorities concerned had failed to take the required "essential measures" against fire and timberpoaching. "Anti-social elements"--fishstealers, litter-droppers, and others who have not yet learned the norms of behaviour proper to a socialist society -present another possible environmental threat. They too are the subject of exhortation in the media, particularly at the local level; on occasion, the state-sponsored Society of the Friends of Nature has been called upon to organise vigilantes to deal with a particular outbreak of "hooliganism".

These, one might conclude from Gerasimov, are the main dangers to the Soviet environment-fairly local and minor disturbances, far down the administrative and social ladder. In fact, the problem is somewhat more complex. The Soviet authorities have in recent years become increasingly aware that their natural resources, though vast, do not constitute the infinity promised to Peter the Great by his geographers. At the Twenty-Fourth Party Congress in 1971, Mr Brezhnev stressed this new approach: "As we take steps to accelerate scientific and technological progress," he said, "we must ensure that this is combined with the rational use of natural resources and should not cause dangerous pollution of air or water, nor exhaust the soil",

This marks a fairly new approach. The early years of the Soviet Union were marked by rapid industrialisation. On posters and cartoons, the smoking factory chimney became the standard symbol for progress. In accordance with Lenin's equation (Communism $=$ Socialism + Electrification), rivers were dammed and spillways built with little, if any concern for the ecological consequences. The writings of Marx dwell mainly on the urban proletariat and barely touch on conservation; and from Lenin's work isolated quotations can he extricated to serve as slogans. Concern was directed more towards utilising than conserving natural resources; of the major theoreticians, only Engels showed concern with the long-term outcome of remodelling the environment. For many reasons, per- haps ideological as well as practical, the relevant passages seemed to make little impression on the planners. To turn rivers aside from their courses, to plant orchards where there once were deserts, to carpet the barren steppe with horizon-to-horizon grain-fields-such achievements, as well as bringing immediate economic benefits, would demonstrate at home and abroad the intrinsic superiority of the Soviet system of planning.

In the 1920s, of course, in spite of industrial expansion during the last decades of Tsarism, the vast majority of the Soviet Union was still in the state of a country emerging from fcudalism, and a system of tied serfdom remained within living memory. Thus, after some elementary laws were passed-the nationalisation of land, the prohibition of fish poaching, the establishment of certain national parks and health resorts-little attention was given to ecological problems: the drive to take the country into the twentieth century outweighed all other considerations. Only two major pieces of conservation legislation were passed under Stalin. These dealt with the establishment of "shelter belts" of trees to prevent erosion (1948) and the control of air pollution (1949), and the first remained something of a dead letter.

Only during the late 1950s, under Khrushchev's policy of opening up undeveloped areas, were a large number of laws passed on conservation and the environment, reflecting a growing awareness of the need for a coherent policy in this field. In many cases, the laws passed at that time set extremely high standards, as though they were intended as "socialist ideals" rather than practical policies: in certain cases virtually the same law was promulgated several times, suggesting considerable difficulties in implementation. Nevertheless, the laws were published in the press and became common knowledge. In the atmosphere of "the thaw", concerned individuals began to voice protests against the most flagrant infringements either officially, or, later, through the samizdat literature. Furthermore, the growing international concern with conservation impelled the Soviet authorities, if only for prestige reasons, to show that the homeland of socialism was not lagging behind in its concern about a universally pressing problem. It is now clear that many of the "developers" were, by present standards, carried too far by their zeal. Many recent Soviet "achievements" in 
conservation are, in fact, motivated by the need to clean up the mess of a former generation.

The case of Lake Baikal

A classic example of this is the case of Lake Baikal. This lake, the deepest in the world, has long been famous for its pure water and its extensive flora and fauna, with 708 unique types of living organisms, including freshwater seals. In Moscow News Gerasimov announced proudly, "It can be definitely said now that Lake Baikal will not die of pollution, as have many other lakes in the world". Under the Tsars, virtually the sole contact between Lake Baikal and the world of industry was the Trans-Siberian railway which skirted part of its southern shore. Inevitably, perhaps, the forests of the Baikal region came to be utilised, and the tributaries of the lake used for rafting timber prior to its further shipment down the Angara, Baikal's sole outlet. But the construction of cellulose and pulp mills in the unique habitat of Lake Baikal seemed odd in a system claiming to use natural resources "rationally" for the good of present and future generations.

The plans for the mills were approved in 1957 , but it was not until 1962 that the first authoritative protests began with an article in Komsomolskaya Pravda by the Director of the Limnological Institute of the Siberian Branch of the Soviet Academy of Sciences. Over the following decade, numerous similar articles were published, notably in Literaturnaya Gazeta and Priroda; Gerasimov himself was prominent in the campaign. Since campaigns of this nature in the State press (as opposed to the samizdat network) can only take place with tacit approval from Government bodies involved, there was either a high-level interdepartmental dispute over Lake Baikal or at least an effort to show official concern.

The indications are that there was opposition from the Academy of Sciences, the Geographical Society of the USSR, and the Expert Commission for the Coordination of Scientific Research. Nevertheless, under the auspices of the Ministry for Timber Production, the mills were built and began operation, discharging effluent into the lake. Even when effluent treatment installations were fully operational, the water discharged was yellowish and barely potable, and by no means comparable in quality with the original lake water. The only sound "economic" reason ever offered for the siting of the mills was the exceptional purity of the Baikal water-a purity needed for the production of certain high-quality products. As early as 1965, however, it was observed that water from the effluent outfall was being carried back by the current to the "pure" water inlet of the mills (Priroda, No. 11, 1965). Consequently it was necessary to process the intake water before use. This demanded the installation of expensive pre-treatment equipment the authorities had hoped to avoid by using Baikal water in the first place.

During the last five-year plan, considerable attention was devoted to the problem of the Baikal habitat. New legislation with Party backing was introduced in September 1971, and a special "emergency charter" was approved by the Ministry of Land Reclamation and Water Economy in November 1974. Timber-felling was forbidden within a radius of $50 \mathrm{~km}$ of the lake, and the tributaries of Baikal have been cleared of the sunken timber which might have absorbed much of the oxygen from the water and covered fish-breeding grounds; "very costly" outfall treatment plant has been installed at the cellulose mills, and whitefish hatcheries have been introduced to replenish depleted stocks.

Lake Baikal has always been of keen interest to ecologists throughout the world, but more recently it has attracted increased attention because of the construction of the Baikal-Amur Railway. Ecological restrictions relating to this at times verge on the absurd (workers must not spray mosquitoes with insecticide) or over-zealous (devastated areas from natural forest fires on the route are to be planted with seedlings, rather than left to regenerate naturally). But if all the recommendations are carried out, the future of Baikal is certainly assured, and the lake and its environs could well become an ecological show-place. The decision to admit American scientists to observe and participate in research on the lake suggests that already the worst hazards have been dealt with. which is gratifying. But the general question remains whether state ownership of resources entails their best use and protection.

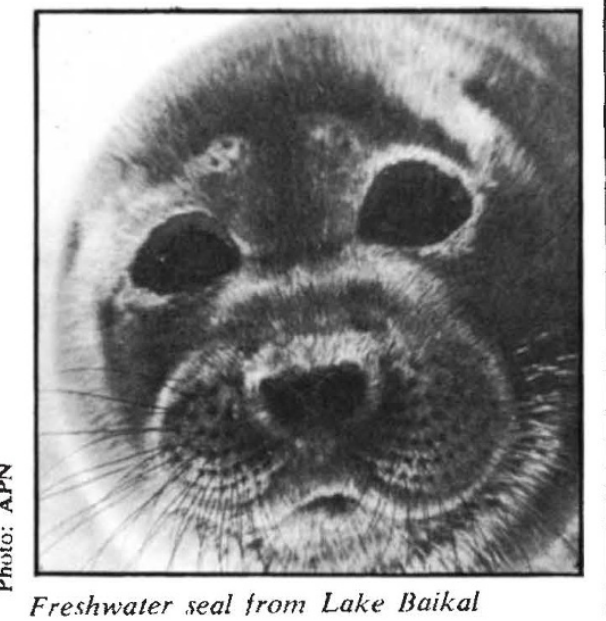

CANADA

SINCE the beginning of the year the outlook for Canadian science and technology for 1976 has not seemed a particularly optimistic one. The Ministry of State for Science and Technology, contrary to some predictions, did manage to survive the federal government's anti-inflation programme which killed off a number of other federal initiatives such as Information Canada, the Company of Young Canadians and Opportunities for Youth, and reduced others, such as the Local Initiatives Program. But the programme still means less money for science and technology generally.

Specifically, the Industrial Research and Development Incentives Act, which has provided between $\$ 20$ million and \$30 million a year for industrial research, will be repealed; reductions will be made in the Programme for Advancement of Industrial Technology and the Defence Industry Productivity Programme; and medical and other scientific research grants will be frozen.

The cuts were made in an attempt to prove to Canadians that the federal government was serious about fighting inflation. and that it intended to set an example. But since then the Prime Minister has gone further, telling the Canadian people that the anti-inflation measures are in fact attempts to control an economy that proved itself unable to work as a free market system-a remark that produced angry responses, including a call for an election by a former Progressive Conservative Cabinet minister

Altogether, the government said it would cut $\$ 1,500$ million from its future spending plans. The loss to scientific research funds was estimated at $\$ 14.8$ million and to industrial incentives at $\$ 8$ million. These are losses that the scientific community mostly regards as insupportable, in the light of the federal government's recent policies and the impact of inflation.

In a letter to the editor of the Toronto Globe and Mail, John Polanyi, Professor of Chemistry at the University of Toronto, pointed out that the total funds available to the National Research Council (NRC), the chief funding hody for fundamental research in Canada, will have increased at an average rate of only $2.5 \%$ a year from 1969 to 1977 , while the cost of doing research during the same period had increased by $100 \%$.

The NRC grants committees, on which he has served, "are quite unable to keep existing research projects of high promise moving ahead. while at the same time giving a genuine opportunity to the scientists of tomorrow to prove their mettle". And, he went on, 